\title{
Response to the letter of Morán et al. regarding our use of an inaccurate reference for the maximal dose of vitamin C in G6PD deficiency
}

\author{
Patrick M. Honore ${ }^{1 *}$, Herbert D. Spapen ${ }^{2}$, Paul Marik ${ }^{3}$, Willem Boer ${ }^{4}$ and Heleen Oudemans-van Straaten ${ }^{5}$
}

To the editor,

We thank Morán et al. [1] for their very attentive reading of our review on vitamin $C$ dosing during renal replacement therapy [2], thereby noticing that one of the cited references [3] had been retracted. We used this retracted reference to support the assertion that a vitamin $C$ dose up to $6 \mathrm{~g} /$ day was not contraindicated in patients with glucose-6-phosphate dehydrogenase (G6PD) deficiency. In fact, the retraction notice appeared about 1 year after the original publication and unfortunately overlapped the first submission of our review. We sincerely apologize for missing this important item and completely agree with Morán et al. to eliminate the reference from our review.

Still, scarce data from the literature suggest that a vitamin $C$ dose up to $6 \mathrm{~g}$ /day can be safely administered to patients with G6PD. Methemoglobinemiathe presence of methemoglobin in the blood-is most commonly treated with methylene blue [4]. However, methylene blue cannot be used in G6PD deficiency because it is ineffective and may even worsen G6PD deficiency-related hemolysis [4]. In vitro data going back to 1979 demonstrated that a vitamin C plasma concentration up to $5 \mathrm{mmol} / \mathrm{L}$ inhibited oxidation of oxyhemoglobin and Heinz body formation in G6PDdeficient red cells incubated with the strong oxidizing

\section{Springer Open}

*Correspondence: Patrick.Honore@CHU-Brugmann.be

${ }^{1}$ ICU Dept, Centre Hospitalier Universitaire Brugmann-Brugmann

University Hospital, Place Van Gehuchtenplein, 4, 1020 Brussels, Belgium

Full list of author information is available at the end of the article drug acetylphenylhydrazine [5]. Applying a dosing regimen of $1.5 \mathrm{~g}$ IV q6h, vitamin $\mathrm{C}$ serum concentrations are typically situated between 200 and $600 \mu \mathrm{mol} / \mathrm{L}$ [6]. Acute hemolytic anemia in a patient with severe methemoglobinemia and G6PD deficiency successfully resolved within $24 \mathrm{~h}$ following strictly monitored administration of $1 \mathrm{~g}$ vitamin $\mathrm{C}$ q6h [4]. However, a recent review reported that vitamin $C$ doses of 4 to $6 \mathrm{~g}$ may propagate hemolysis [7]. This illustrates that vitamin $\mathrm{C}$ administration in G6PD patients requires caution. Alternative treatment [4] should be preferred if methemoglobinemia develops. In the absence of a valid alternative, a maximal IV dose of 4 to $6 \mathrm{~g}$ vitamin $\mathrm{C}$ could be considered, provided that strict monitoring is guaranteed. Meanwhile, it is wise to exclude patients with known or suspected G6PD deficiency from studies evaluating the use of $6 \mathrm{~g}$ vitamin $C$ in populations that may benefit from this therapy such as septic shock or burn patients.

\section{Abbreviation \\ G6PD: Glucose-6-phosphate dehydrogenase.}

\section{Acknowledgements}

We would like to thank Dr. Melissa Jackson for critical review of the manuscript.

\section{Authors' contributions}

PMH, HDS, PM, WB and HOV designed the paper. All authors participated in drafting and reviewing. All authors read and approved the final manuscript.

\section{Funding}

None.
(0) The Author(s) 2020. This article is licensed under a Creative Commons Attribution 4.0 International License, which permits use, sharing, adaptation, distribution and reproduction in any medium or format, as long as you give appropriate credit to the original author(s) and the source, provide a link to the Creative Commons licence, and indicate if changes were made. The images or other third party material in this article are included in the article's Creative Commons licence, unless indicated otherwise in a credit line to the material. If material is not included in the article's Creative Commons licence and your intended use is not permitted by statutory regulation or exceeds the permitted use, you will need to obtain permission directly from the copyright holder. To view a copy of this licence, visit http://creativeco mmons.org/licenses/by/4.0\%. 
Availability of data and materials

Not applicable.

Ethics approval and consent to participate

Not applicable.

\section{Consent for publication}

Not applicable.

\section{Competing interests}

The authors declare to have no competing interests.

\section{Author details}

${ }^{1}$ ICU Dept, Centre Hospitalier Universitaire Brugmann-Brugmann University Hospital, Place Van Gehuchtenplein, 4, 1020 Brussels, Belgium. ${ }^{2}$ Medicine, Development, Ageing \& Pathology Research Department, Vrije Universiteit Brussel, Brussels, Belgium. ${ }^{3}$ Division of Pulmonary and Critical Care Medicine, Eastern Virginia Medical School, 825 Fairfax Av, Suite 410, Norfolk, VA 23507, USA. ${ }^{4}$ Dept of Anesthesiology, Intensive Care Medicine, Emergency Medicine \& Pain Medicine, Ziekenhuis Oost-Limburg, Genk, Belgium. ${ }^{5}$ Department of Intensive Care Medicine, Amsterdam UMC, Vrije Universiteit Amsterdam, De Boelelaan 1117, 1081 HV Amsterdam, The Netherlands.

Received: 25 June 2020 Accepted: 30 June 2020

Published online: 10 July 2020

\section{References}

1. Morán JM, Herrera-Peco I. Commentary to "Dosing vitamin C in critically ill patients with special attention to renal replacement therapy: a narrative review". Ann Intensive Care. 2020. https://doi.org/10.1186/s136 3-020-00710-7.
2. Honore PM, Spapen HD, Marik P, Boer W, Oudemans-van Straaten H. Dosing vitamin C in critically ill patients with special attention to renal replacement therapy: a narrative review. Ann Intensive Care. 2020;10:23. https://doi.org/10.1186/s13613-020-0640-6.

3. Wu S, Wu G, Wu H. Hemolytic jaundice induced by pharmacological dose ascorbic acid in glucose-6-phosphate dehydrogenase deficiency: a case report: retraction. Medicine (Baltimore). 2019;98(48):e18261. https://doi. org/10.1097/MD.0000000000018261.

4. Rehman A, Shehadeh M, Khirfan D, Jones A. Severe acute haemolytic anaemia associated with severe methaemoglobinaemia in a G6PD-deficient man. BMJ Case Rep. 2018. https://doi.org/10.1136/bcr-2017-223369.

5. Winterbourn CC. Protection by ascorbate against acetylphenylhydrazine induced Heinz body formation in glucose-6-phosphate dehydrogenase deficient erythrocytes. Br J Haematol. 1979;41:245-52.

6. Marik PE. Is intravenous vitamin C contraindicated in patients with G6PD deficiency? Crit Care. 2019;23(1):109. https://doi.org/10.1186/s1305 4-019-2397-6.

7. Yanase F, Fujii T, Naorungroj T, et al. Harm of IV high-dose vitamin C therapy in adult patients: a scoping review. Crit Care Med. 2020. https:// doi.org/10.1097/CCM.0000000000004396.

\section{Publisher's Note}

Springer Nature remains neutral with regard to jurisdictional claims in published maps and institutional affiliations.

\section{Submit your manuscript to a SpringerOpen ${ }^{\circ}$ journal and benefit from:}

- Convenient online submission

- Rigorous peer review

- Open access: articles freely available online

- High visibility within the field

- Retaining the copyright to your article

Submit your next manuscript at $\boldsymbol{\nabla}$ springeropen.com 